\title{
Correlation of Serum zinc with TSH in hyperthyroidism
}

\author{
Satwika Sinha1, Kaushik Kar1, Anindya Dasgupta², Saubhik Basu³, Sukanta Sen ${ }^{4}$ \\ ${ }^{1}$ Assistant Professor, Department of Biochemistry, Calcutta National Medical College, Kolkata, India, ${ }^{2}$ Professor, Department of Biochemistry, \\ Calcutta National Medical College, Kolkata, India, ${ }^{3}$ Post Graduate Student, Department of Biochemistry, Calcutta National Medical College, \\ Kolkata, India, ${ }^{5}$ Associate Professor, ICARE Institute of Medical Sciences and Research, Haldia, West Bengal
}

\section{A B S TRACT}

Aims and Objectives: Trace elements may have a role in progression of hyperthyroidism. We planned to estimate the serum zinc, copper and ceruloplasmin in hyperthyroids. Materials and Methods: 41 hyperthyroid patients and 32 control subjects were taken for the study. Serum T4, TSH, zinc, copper and ceruloplasmin were estimated in them. T4 and TSH were estimated by ELISA method. Zinc and copper were estimated by colorimetric method. Serum ceruloplasmin were estimated by Ravins method. Results: Significant decrease of TSH $(p<0.0001)$ and zinc $(p<0.0001)$ were found in hyperthyroids in comparison to controls. Serum copper and ceruloplasmin were significantly elevated $(p<0.0001)$ in them. Significant positive correlation between TSH and zinc was observed in case group. Conclusion: Zinc deficiency may contribute to the worsening of hyperthyroidism. Zinc supplementation may improve the condition.

Key words: Hyperthyroidism, TSH, Serum zinc, Serum copper, Ceruloplasmin
Access this article online

Website:

http://nepjol.info/index.php/AJMS

DOI: 10.3126/ajms.v7i1.12895

\section{INTRODUCTION}

Commonest endocrine disorders of world are the thyroid diseases. Population study estimated about 108 million people in India are suffering from endocrine and metabolic diseases of which thyroid abnormalities contribute about 42 millions. ${ }^{1}$ Hyperthyroidism may results from generalised thyroid gland over activity or due to some other causes. ${ }^{2}$ However clinical, physiological and biochemical alterations occur when tissues are exposed to increased concentrations of thyroid hormones. ${ }^{3}$ Different studies also supported that functional abnormalities of hyperthyroidism virtually affects many organ systems. ${ }^{4}$

An epidemiological study in cochin have shown that subclinical and overt hyperthyroidism were present in $1.6 \%$ and $1.3 \%$ of subjects in community. ${ }^{5}$ In another hospital based study at Puducherry, $0.6 \%$ and $1.2 \%$ of female subjects were observed as hyperthyroids. ${ }^{6}$

Optimal health maintenance demands an adequate supply of macronutrients, micronutrients and trace elements. ${ }^{7}$ Trace elements influence hormones on different aspects, namely hormone secretion, binding at target tissues and actions. ${ }^{8}$
With the known effect of zinc ( $\mathrm{Zn})$ on hypothalamus and pituitary, it appears a major role in the synthesis of thyrotropin releasing hormone(TRH) ${ }^{9,10}$ It also shows its necessity in the activity of 5 " deiodenase. ${ }^{11}$ Studies already documented the alteration of $\mathrm{Zn}$ status in hypothyroidism. ${ }^{12,13}$ Significantly low $\mathrm{Zn}$ levels were found by Kucharzews-ki et al in patients with thyroid cancer. ${ }^{14}$ In another study low $\mathrm{Zn}$ and high copper $(\mathrm{Cu})$ levels were observed in thyroid cancer patients. ${ }^{15}$ The alteration of $\mathrm{Zn}, \mathrm{Cu}$ and manganese were observed in erythrocytes and brain tissues of rats in induced iodine deficiency ${ }^{16}$ Plasma $\mathrm{Cu}$ is mostly bound to ceruloplasmin (CP) and only a small fraction is bound to albumin. ${ }^{17}$ Furthermore, increased (S) $\mathrm{CP}$ levels were observed in hyperthyroidism were established by some authors. ${ }^{18}$ Following the above observations, the present study aimed to explore the changes in the serum levels of $\mathrm{Zn}, \mathrm{Cu}$ and $\mathrm{CP}$ in hyperthyroid patients and any correlations exists between them.

\section{MATERIALS AND METHODS}

The study was done in the Biochemistry department of Calcutta National Medical College. It is a Cross sectional, 
observational study without any type of intervention. The duration of study was two months (1.7.2014 to 31.8.2014).

Selection of cases and controls- A total of 41 hyperthyroid (16 males and 25 females, aged 25 to 50 years) patients were selected for the study. Written informed consent was taken from them. 32 age and sex matched controls were also selected, with consent, from apparently healthy persons who were not suffering from any diseases.

\section{Inclusion criteria}

Selection was done according to method of convenience. All patients for estimation of thyroid status according to the advice of physicians and Surgeons of different departments of the institution.

\section{Exclusion criteria}

a) Patients suffering from any other endocrine disorders like diabetes mellitus

b) Any other disease or drugs which may cause alteration of $\mathrm{Zn}, \mathrm{Cu}$ or CP levels

c) Antenatal mothers and psychiatry patients

d) Smokers and tobacco chewers.

Methods for analysis of test parameters: The assessment of cases and controls was done under 3 headings, history, clinical examination, and biochemical assay. For biochemical assay, $5 \mathrm{ml}$ of blood from the subjects was collected aseptically using standard protocols. The serum was separated by centrifugation (3000 rpm for $5 \mathrm{~min}$ ) immediately and analysis was done.

Estimation of T4 was done by Competitive ELISA. (Aspen Laboratories Pvt Ltd). ${ }^{19}$

Estimation of TSH was done by Sandwich Elisa (Aspen Laboratories Pvt Ltd). ${ }^{20}$

Serum zinc is measured by colorimetric method.(Crest Biosystems). ${ }^{21}$

Serum copper is measured by colorimetric method.(Crest Biosystems). ${ }^{22}$

Serum ceruloplasmin is measured by Ravin`s method. ${ }^{23}$

\section{Ethics}

Before commencement of the work, Ethical Permission was obtained from the Institutional Ethics Committee, according to the Helsinki Declaration. Written informed consent was taken from cases and control subjects.

\section{Statistical analysis}

Statistical analysis was done by SPSS 20 Software. Individual parameters are compared in between control and hyperthyroid group by unpaired students t-test. Correlation coefficient was done by pearsons correlation 2 tailed. $\mathrm{P}$ value was considered significant when $<0.05$.

\section{RESULTS}

Results of our study have clearly shown that mean serum TSH \& Zn values were significantly low $(\mathrm{P}<0.001)$ in hyperthyroid patients than controls (Table 1) and mean serum cu \& CP was significantly high $(\mathrm{P}<0.001)$ in case group when compared to controls (Table 1 ). Our results also have shown significant positive correlation between TSH and Zn levels (Table 2).

\section{DISCUSSION}

The current study has shown significant decrease of serum $\mathrm{Zn}$ levels in hyperthyroidism. Our result is in agreement with the results of some previous studies. ${ }^{24-27}$ Maes et al showed that (S) $\mathrm{Zn}$ and albumin were significantly decreased in hyperthyroid patients. ${ }^{28}$ The probable explanation is that the albumin is the major transporter of $\mathrm{Zn}$ in plasma. ${ }^{29}$ They also suggested that the lower (S) Zn level in hyperthyroidism may be secondary to the sequestration of metallothioneins in liver, which may be a response of increased production of interleukin-6 (IL-6) produced during inflammation. ${ }^{28}$ Furthermore, Varga et $\mathrm{al}^{30}$ found the decrease of RBC $\mathrm{Zn}$ content may be a reflection of reduced (S) Zn in hyperthyroidism. Influence of TSH may also contribute the alteration of (S) $\mathrm{Zn}$ in

\section{Table 1: Student's t test of various parameters}

\begin{tabular}{|c|c|c|c|}
\hline \multirow[t]{2}{*}{ Parameter } & \multicolumn{2}{|c|}{ Mean士SD } & \multirow[t]{2}{*}{$P$ value } \\
\hline & Control $(n=32)$ & Case $(n=41)$ & \\
\hline $\mathrm{TSH}$ & $3.0381 \pm 0.037534$ & $0.2049 \pm 0.02410$ & 0.0001 \\
\hline $\mathrm{T}_{4}$ & $5.9375 \pm 1.11416$ & $21.1220 \pm 6.83731$ & 0.0001 \\
\hline Zinc & $90.5938 \pm 2.29810$ & $48.9268 \pm 3.48848$ & 0.0001 \\
\hline Copper & $109.0313 \pm 7.68528$ & $163.5366 \pm 2.70275$ & 0.0001 \\
\hline Cerruloplasmin & $31.9375 \pm 3.08939$ & $50.4878 \pm 3.17901$ & 0.0001 \\
\hline
\end{tabular}

\begin{tabular}{lcc}
$\begin{array}{l}\text { Table 2: Pearson correlations for Zinc \& TSH in } \\
\text { hyperthyroid group }\end{array}$ & \\
\hline Group variable & TSHd & Znd \\
\hline TSHd & 1 & $0.314^{*}$ \\
$\quad$ Pearson correlation & & 0.046 \\
$\quad$ Sig. (2-tailed) & 41 & 41 \\
N & & \\
Znd & $0.314^{*}$ & 1 \\
$\quad$ Pearson correlation & 0.046 & 41 \\
Sig. (2-tailed) & 41 & \\
N & *
\end{tabular}


human thyroid tissue. ${ }^{31}$ In our study we have found a significant positive correlation between (S) TSH and (S) Zn concentrations among hyperthyroids.

Cousins R et al observed the ${ }^{32}$ interleukin 1 (IL-1) produced a transient decrease of (S) $\mathrm{Zn}$ and increase (S) CP. They also found the infection, cellular injury and inflammation may stimulate the IL-1 production which results the increased metallothionein content in liver. In agreement with this, we found the rise of (S) CP in hyperthyroids.

We observed significant rise of cu concentration in hyperthyroids when compared to controls. Our study is in agreement with the findings of Aihara $\mathrm{K}$ et al. ${ }^{33}$ Most of the plasma cu is bound to CP and only a small portion is bound to plasma albumin. ${ }^{34}$ Hence rise of $(\mathrm{S})$ cu may be a result of increased CP in hyperthyroidism. ${ }^{35}$ Plasma CP level was also reported to be increased in patients with hyperthyroidism. ${ }^{36} \mathrm{~A}$ possible explanation is that the $\mathrm{CP}$ is one of the acute phase reactant that increases in response to inflammation. ${ }^{29}$ Although our study have shown the significant alteration of $\mathrm{Zn}, \mathrm{Cu}$, and $\mathrm{CP}$ in hyperthyroids in comparison to controls, significant positive correlation was observed between $(\mathrm{S})$ TSH and Zn. Based on the observations of our study, we can hypothesize that $\mathrm{Zn}$ reduction may contribute in development or progression of hyperthyroidism. These results may help the physicians to think and plan about Zn supplement in hyperthyroids.

\section{CONCLUSION}

The results of our study have shown the significant alteration of $\mathrm{Zn}, \mathrm{Cu}$ and $\mathrm{CP}$ in hyperthyroid patients. Furthermore we also observed a significant positive correlation between TSH and Zn. Zinc reduction may be a contributor of worsening of hyperthyroidism. Zinc supplementation may improve the condition.

\section{REFERENCES}

1. Kochupillai N. Clinical endocrinology in India. Current Science 2000; 79(8):1061-1066.

2. Burrow GN, Fisher DA and Larsen PR. Maternal and fetal thyroid function. N Engl J Med 1994; 331: 1072-1078.

3. Ludgate $M$, Crips $M$, Lance $C$, Costagliola S, Vassart G, Weetman $A$, et al. The thyrotropin receptor in thyroid eye disease. Thyroid 1998; 8: 411-423.

4. Kung AW. Life events, daily stresses and coping in patients with Graves' disease. Clin Endocrinol.- Oxf 1995; 42: 303-308.

5. Usha Menon V, Sundaram KR, Unnikrishnan AG, Jayakumar RV, Nair $\mathrm{V}$ and Kumar $\mathrm{H}$. High prevalence of undetected thyroid disorders in an iodine sufficient adult south Indian population. J Indian Med Assoc 2009;107:72-77.

6. Abraham R, Murugan VS, Pukazhvanthen P and Sen SK.
Thyroid Disorders In Women of Puducherry. Indian J Clin Biochem 2009;24:52-59.

7. Solomons N. Trace Elements. In Clinical Nutrition: Parenteral Nutrition $2^{\text {nd }}$ ed. Philadelphia, pp 150-183.

8. Henkin RI. Trace Elements in Endocrinology. Medical Clinics of North America 1976; 60: 779.

9. Brandao Neto J, Saturnino A, Leite LD, De Mederios-Rocha ED, Marcos CMP, Da Silva CAB, et al. Lack of acute zinc effect on thyrotropin releasing hormone-stimulated thyroid-stimulating hormone secretion during oral zinc tolerance test in healthy men. Nutr Res 2006;26:493-496.

10. Pekary AE, Lukaski HC, Mena I and Hershman JM. Processing of TRH precursor peptides in rat brain and pituitary is zinc dependent. Peptides 1991;12:1025-1032.

11. Wada $L$ and King JC. Effect of low zinc intakes on basal metabolic rate, thyroid hormones and protein utilization in adult men. J Nutr 1986;116:1045-1053.

12. Majewask U, Braziewicz J, Banas D, Kubala- Kukus A, Kuchrazewski M, Waler J, et al. Zn concentration in thyroid tissue and whole blood of women with different diseases of thyroid. Biol Trace Elem Res 2001;80:193-199.

13. Zhang $F$, Liu N, Wang $X$, Zhu L and Chai Z. Study of trace elements in blood of thyroid disorder subjects before and after 131I therapy. Biol Trace Elem Res 2004;97:125-134.

14. Kucharzewski M, Braziewich J, Majewska $U$ and Gozdz S. Copper, zinc, and selenium in whole blood and thyroid tissue of people with various thyroid diseases. Biol Trace Elem Res 2003;93:9-18.

15. Al-Sayer H, Mathew TC, Asfar S, Khourshed M, Al-Bader A, Behbehani $A$, et al. Serum changes in trace elements during thyroid cancers. Mol Cell Biochem 2004;260:1-5.

16. Liu NQ, Xu Q, Hou XL, Liu PS, Chai ZF, Zhu L, et al. The distribution patterns of trace elements in the brain and erythrocytes in a rat experimental model of iodine deficiency. Brain Res Bull 2001;55:309-312.

17. Tyrala E, Brodsky $\mathrm{N}$ and Auerbach V. Urinary copper losses in infants receiving free amino acid solutions. Am J Clin Nutr 1982;35: 542-545.

18. Erkillic $A B$, Aliciguzel $Y$, Erkillic $M$ and Aksu A. Ceruloplasmin and Vit $E$ levels in toxic multinodular goitre. Nutri Res 1996;16 (2):185-189.

19. Schall RF, Fraser AS, Hansen HW, Kern CW and Teneso HJ. A Sensitive Manual Enzyme Immunoassay for Thyroxine. Clin. Chem 1978;24 (10): 1801.

20. Burger HG and Patel YC. Thyrotropin releasing hormone-TSH Clinic. Endocrinol. and Metab 1977; 6:831- 00.

21. Tetsus Makino. Estimation of Serum Zinc. Clin Chem Acta 1991; 197: 209-220.

22. Akita Abe and Yiamashita S. Estimation of Serum Copper. Clin Chem 1989; 35(4) 552-554.

23. Ravin HA. An improved colorimetric enzymatic assay of ceruloplasmin. J Lab Clin Med 1961;58:161-168.

24. Vitoux D, Arnaud $\mathrm{J}$ and Chappuis P. Are copper, zinc and selenium in erythrocytes valuable biological indexes in nutrition and pathology? J Trace Elem Med Biol 1999 13;113-128.

25. Yoshida K, Kiso Y, Watanabe T, Kaise K, Kaise N and Itagaki M. Erythrocyte zinc in hyperthyroidism: Reflection of integrated thyroid hormone levels over the previous few months. Metabolism 1990; 39:182-186.

26. Tsou CT and Chen MD. Alterations of zinc levels in patients with thyroid disorders. Chung-Hua-I-Hsueh-Tsa-Chih-Taipei 1993; 51:57-60.

27. Sayama N and Yoshida K. Measurement of red blood cell zinc 
concentration between with Zn- test kit: Discrimination between hyperthyroid Grave's disease and transient thyrotoxicosis. Endocr J 1998; 45:767-772.

28. Maes M, Devos N, Demedts P, Wauters A and Neels H. Lower serum zinc in major depression in relation to changes in serum acute phase proteins. J Affect Disord 1999; 56(2-3): 189-194.

29. Ali EA, Tahssen $\mathrm{YH}$ and Saleh BO. Study of some trace elements in hyperthyroidism patients. The Iraqi Postgraduate Med Jour 2007; 6(2):113-117.

30. Varga F, Tarjan G, Steczek K and Foldes J. Zn-content of erythrocytes in overt and subclinical hyperthyroidism. Orv-Hetil 1994; 135: 1183-1185.

31. Bellisola G, Bratter P, Cinque G, Francia G, Galassini S, Gawlik D, et al. The TSH-dependent variation of the essential elements iodine, selenium and zinc within human thyroid tissues.
J-Trace-Elem-Med-Biol 1998; 12:177-182.

32. Cousins $R$ and Leinart $A$. Regulation of cellular immune response by selenium. FASEB J 1988; 2:2884-2890.

33. Aihara K, Katsuaki A, Nishi $Y$ and Hatano S. Zinc, copper, manganese, and selenium metabolism in thyroid disease. Am J Clin Nutr 1984; 40: 26-35.

34. Tyrala E, Brodsky $\mathrm{N}$ and Auerbach V. Urinary copper losses in infants receiving free amino acid solutions. Am J Clin Nutr 1982; 35: 542-545.

35. Lindsey B. Amino Acids and Proteins. In: Bishop M, Dubin-Engelkirk J, Fody E, editors. Clinical Chemistry; Principles, Procedures, \& Correlations. 4th ed, Lippincott Pub: 2000, pp 294-321.

36. Coburn JW. Disorders of Mineral Metabolism. In: Trace Minerals. New York: Academic Press, 1981, pp 59-92.

\footnotetext{
Authors Contribution:

SS (Sinha) and AD - Designed the study and wrote the protocol. SS (Sinha) - Performed the statistical analysis. KK - wrote the $1^{\text {st }}$ draft of manuscript. Authors SB and SS (Sen) - Managed the analysis of study and literature search. All authors read and approved the final manuscript.
}

Source of Support: Instruments used in this study belongs to West Bengal Government. Reagents are partly supplied by West Bengal Government and rest were brought by the authors, Conflict of Interest: None declared. 